\title{
Product performance evaluation: A case study on thermal insulation in Northeastern Brazil
}

\author{
Miguel Otávio Barreto Campelo de Melo, Sheyla Rodrigues de Resende, Luiz Bueno da Silva, Maria Silene Alexandre leite \\ Federal University of Paraiba \\ e-mails: mobcmelo@ct.ufpb.br; secmestrado@ct.ufpb.br; bueno@ct.ufpb.br, leite@ct.ufpb.br
}

\begin{abstract}
A performance measurement system can be defined as a consistent set of measurements used to quantify the efficiency and efficacy of an organization. Financial and non-financial measurements must be balanced in order to monitor and evaluate the path modern companies must take to promote future performance, suppliers, employees, processes, technology, and innovation. The case study herein analyzed concerns thermal insulation developed from unconventional materials, each with specific properties. The application would occur in the semiarid areas of northeastern Brazil, where the average temperature ranges between $34^{\circ}$ and $40^{\circ} \mathrm{C}$. The product in question reduces heat transfer between indoor and outdoor areas, and creates a thermally comfortable environment. It also reduces the use of electricity for air-conditioning. This paper aims at finding and adapting a performance evaluation model to measure and analyze the performance of new products developed from some unconventional materials, therefore drawing a comparison with similar products already on the market. It is expected that this model generate and organize information that supports decision making.
\end{abstract}

Keywords: product performance evaluation; insulating materials; energy efficient materials.

\section{Introduction}

Institutional changes currently underway in the Brazilian electric sector are intended to establish a free market in energy, increasing the efficiency of the sector by enabling competition and raising funds for expansion. In this market, as elsewhere, participants and performance measurement system can be defined as a consistent set of measurements used to quantify the efficiency and efficacy of one organization. For Nuintin (2007), information resulting from the application of performance evaluation models helps making decisions, correcting deviations in relation to the original plan, and searching for continual improvement in the organization.

Performance evaluation models can be considered a set of dimensions, criteria or characteristics that must be used to evaluate a product, service, process or organization. Recent Thus, performance evaluation models depend on the creation of performance indicators that can be measured. When analysed together, these indicators may translate each one of such dimensions, criteria or characteristics set in the model. This will provide the decision maker with more information and will allow a more adequate evaluation of the analyzed object (TAKASHINA, 1996; MARELLI, 2005; SILVA, 2006; CHUNG; PEARN; LEE, 2006; TAO; CHEN; HSIEH, 2009; WU; WANG; FAN, 2010; RAY; SARKAR; SANYAL, 2011)

The case study herein analysed is a thermal insulator developed from unconventional materials, each with specific properties, to be used in substation buildings in the semiarid areas of northeast Brazil, where the average temperature ranges between $34^{\circ}-40^{\circ} \mathrm{C}$. The aim would be reducing heat transfer between indoor and outdoor areas and creating a thermally comfortable environment, thus reducing the use of electricity for air-conditioning.

This paper aims at finding and adapting a performance evaluation model to measure and analyse the performance of new thermal insulation products developed from unconventional materials. The paper compares these materials to similar products already on the market, thus leading to organizing and generating information that back up decision making.

Although it is possible to visualize the gains achieved with products developed from unconventional materials with thermal insulating properties, it is essential to quantify the benefits in order to demonstrate the marketing potential of these new products, as well as to help further improvements of such thermal insulation. (MELO; SILVA; CAMPELO, 2012).

\section{Environmental thermal comfort}

Thermal comfort has been the subject of much research in the last decades. Such studies have sought to better understand how this could be achieved, how it is processed, which variables it involves, what the most relevant indices are, including their effects on human health and productivity, 
and also to what factors it may be related (MELO; SILVA; CAMPELO, 2012).

The sensation of thermal comfort depends on the combination of the following variables: activity, clothing, temperature, humidity and air velocity, and medium radiant temperature. Thermal environment can be defined as the set of thermal parameters of the job that influence the worker's body, thus being an important factor that influences directly or indirectly on health and well-being, and on carrying out the assigned tasks.

\subsection{Thermal insulating materials}

Several materials are being used and studied to produce thermal insulation that may be applied to buildings. Among these materials are some natural fibres, which are normally combined to some conventional material. The following unconventional materials have been used: gypsum, vermiculite and EVA (ethylene-vinyl acetate) (MELO et al., 2012).

Gypsum, abundant in nature and found in several deposits in northeast Brazil, is water absorbent and keeps air moisture in enclosed areas. It provides good thermal insulation and modest acoustic insulation and, due to its low weight, offers lightness when used in cement block manufacturing.

Vermiculite is a mineral essentially formed by hydrated silicates of aluminium and magnesium and has been widely used in construction. When expanded, vermiculite provides excellent thermal insulation capacity, conducts electricity, and also behaves as an acoustic absorber (Figure 1). Expanded vermiculite produced industrially was used, and the material was purchased in Kraft paper bag (MELO et al., 2012).

EVA is an acetate, which has the advantages of low density polyethylene (LDPE) plus certain polarity, offering mechanical and thermal properties that vary according to purpose. It is produced in large quantities as residue of expanded sheet cuttings from the footwear industry and several studies have demonstrated its ability to be transformed into light gravel possible to be embedded and moulded into plaster boards. Footwear production in Brazil's northeast region has seen a big leap in the last ten years (Figure 2). In the sandal industry established in the region, for example, the estimated average production of shoe polymeric waste is $200 \mathrm{t}$ a month. Considering the high volume generated owing to its low density and the fact that it is not biodegradable, this footwear industry waste becomes a challenge. One application of EVA waste is as an aggregate, be it in mortar production, as a thermal insulation element, or concrete. The product then would be these plaques to be used on walls in order to improve thermal insulation (BEZERRA, 2002; MACAMBIRA, 2001).

\subsection{The thermal insulating plaque}

It was determined, initially, that plates of insulating materials would be used for lining the walls. A model of $40 \mathrm{~cm} \times 40 \mathrm{~cm}$ square plate was proposed, as shown in Figure 3 . The plate has male- and female-type protrusions at the vertices, on each corner, $10.0-\mathrm{cm}$ length $\mathrm{x} 10.0-\mathrm{cm}$ breadth and $3.0-\mathrm{cm}$ thickness, to allow the implementation of the original wall plate. The remaining of the plate is $1.5-\mathrm{cm}$ thick, which involves a low relief that, after application, forms a 1.5 -cm-thick layer of air between the bottom of that plate and the wall on which it is fixed (OLIVEIRA, 2009).

The plates were designed to leave them in a room for upward movement of air due to density variation. The part of the plates that come into contact with the wall gives them adequate support, once they are set. Once installed, the plates are not subjected to bending stress or significant compression. In addition, over time, the matrix, gypsum, retains its properties, provided it is not subjected

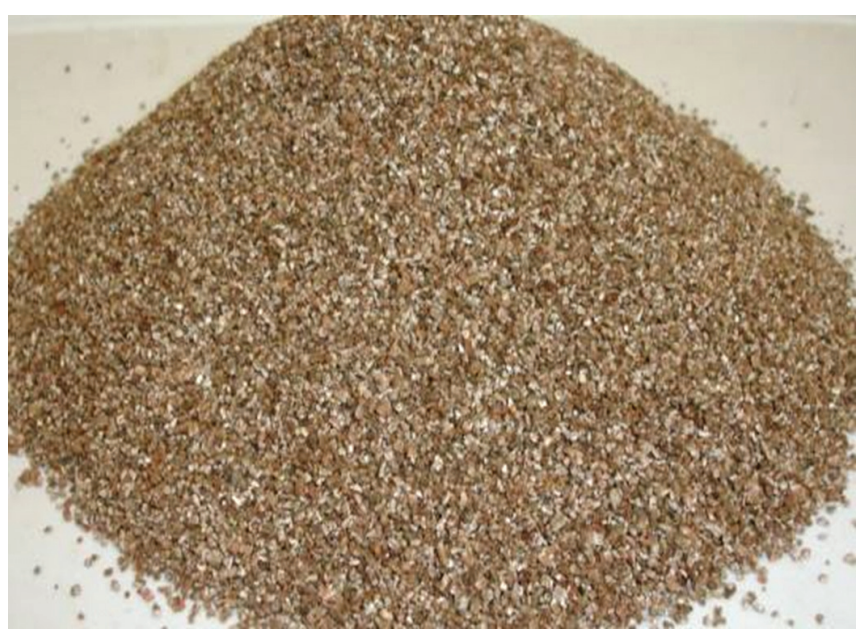

Figure 1. Expanded Vermiculite. Source: Melo et al. (2012).

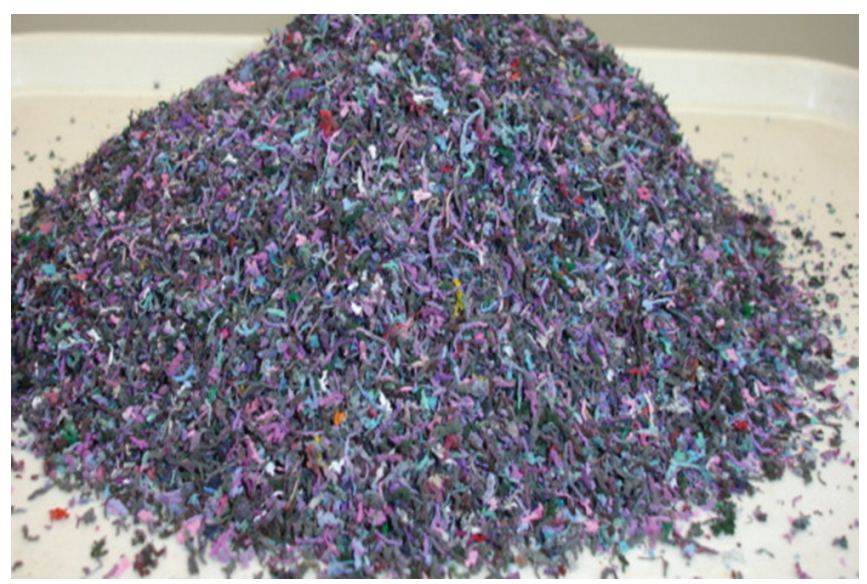

Figure 2. Waste EVA. Source: Melo et al. (2012). 


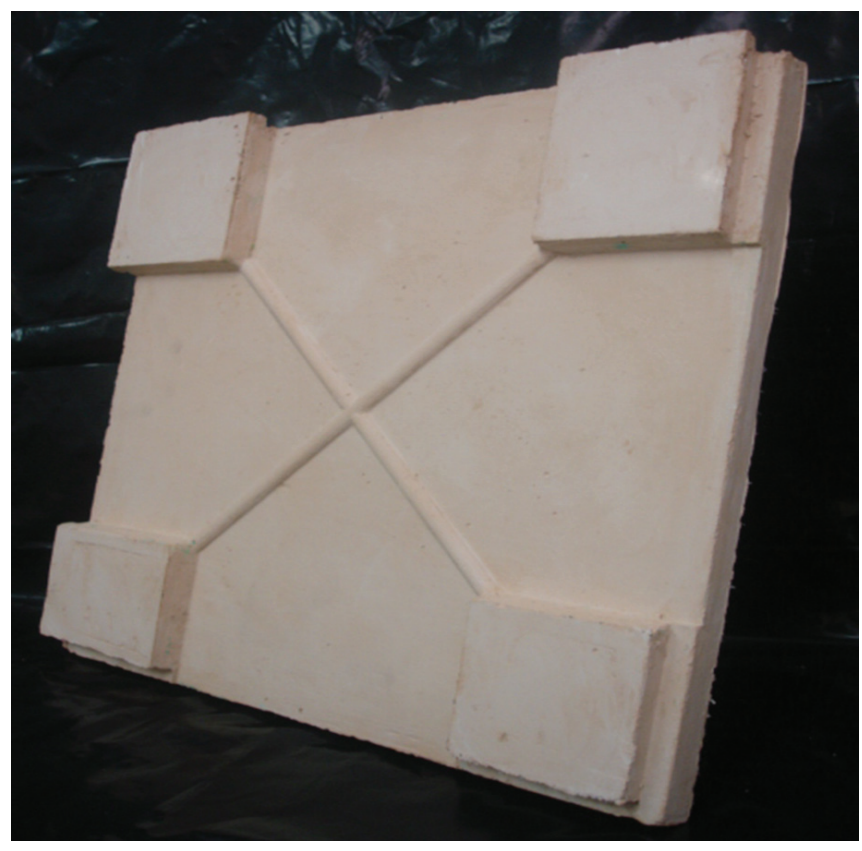

Figure 3. Model board proposal. Source: Oliveira (2009).

to the action of water. As a result, no test was done on the mechanical function of time (OLIVEIRA, 2009).

\subsection{Performance evaluation}

Considering the views of Dutra (2003), Godini (2007), Marelli (2005), O'Mara, Hyland and Chapman (1998), Bourne et al. (2000) and Díaz, Gil and Machuca (2005), on performance evaluation systems, it can be identified that the main goal of such systems is to help a company improve their activities, thus using indicators that meet the company's strategic goals.

Kaplan and Norton (2000) point out that, in a performance evaluation system, financial and non-financial measurements must be balanced, for financial measurements alone are inadequate to monitor and evaluate the path modern companies must take to promote future development, clients, suppliers, employees, processes, technology and innovation. Hanson, Melnyk and Calantone (2011) develop an operational definition of alignment within the context of a performance measurement and management system to create a measurement model that can be used in surveybased research, particularly under conditions of dramatic strategic change. Digalwar and Sangwan (2011) develop a new performance measurement system and proposed a framework for world class manufacturing performance measurement. Bititci et al. (2006) develop a model of the dynamic relationship between performance measurement, management styles and organisational culture, in order to better understanding of the causal linkages between these three areas.
Performance indicators must be able to generate adequate information for the administrator. Information that is supposed to represent one object must be the most reliable and representative as possible. This way, indicators must be set in a measurement system that will recognize, understand, organize and attest to them (GODINI, 2007). Singh, Mittal and Sangwan (2013) analyzed performance measures for manufacturing and to a new paradigm of environmentally conscious manufacturing (ECM) and were identified 11 performance measures with this new paradigm. Franceschini, Galetto and Maisano (2006) shows a classification of performance indicators in manufacturing, providing a mathematical structure to the concept of indicator.

However, it is necessary to ponder that performance measurements when considered alone have little efficacy when measuring the performance results of an organization. Therefore, it is necessary to create a structure of such measures so as to meet the characteristics of each organization, especially concerning the adopted strategy (GODINI, 2007).

Table 1 shows performance evaluation methodologies chosen to be analysed in the current research. Next, the aim and methodology used for each one of these models are presented.

\section{Materials and methods}

According to Table 2, investigation variables are defined to allow reaching the general aim of the research; this is fundamental for selecting and adaptation the evaluation model.

\subsection{Research methodology}

To comply with the general goal set, at first, a performance evaluation model existing in literature was selected and adapted to help the measurement process and, consequently, the decision-making process.

Later, the products for performance evaluation, that is, the developed thermal insulators, were identified and characterized through a description of the materials used in the constitution of the products; identification of technical information such as density, heat capacity, dimensions, among others; and the production process for obtaining the insulation.

In the process of formulating the performance indicators, aspects such as the following were considered: the product performance evaluation, the formula for the index calculation, as well as the frequency of collection, compilation and dissemination of the indices.

Considering the aforementioned information, performance indicators were defined, in order to evaluate all the dimensions determined by the adapted model. Each selected indicator will be described in their own data- 


\begin{tabular}{|c|c|c|c|c|c|c|c|c|}
\hline 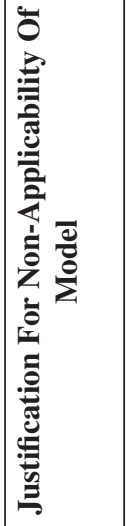 & 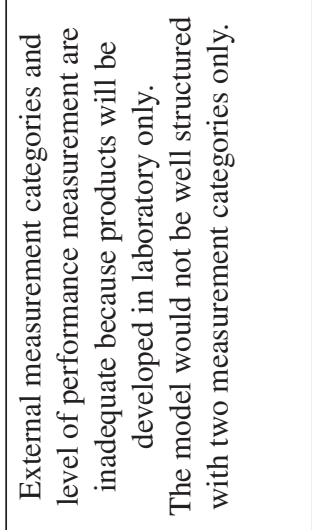 & \multicolumn{3}{|c|}{ 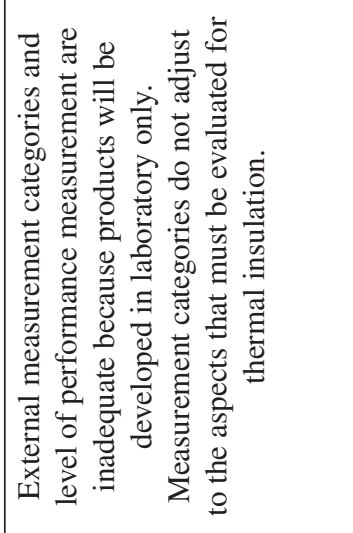 } & 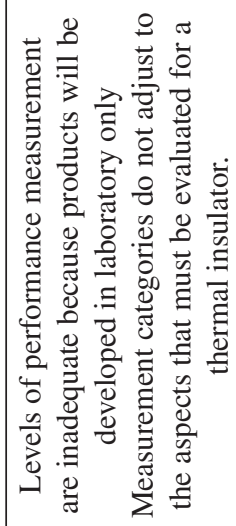 & 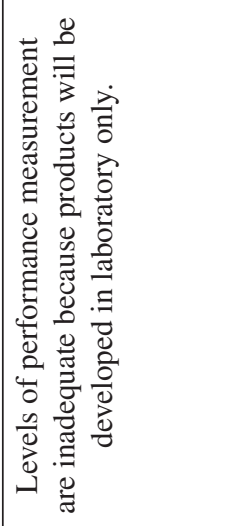 & 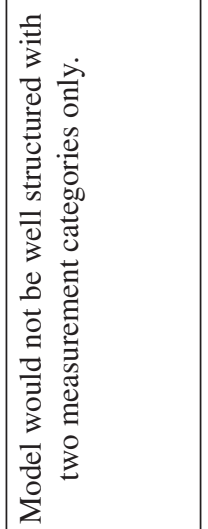 & 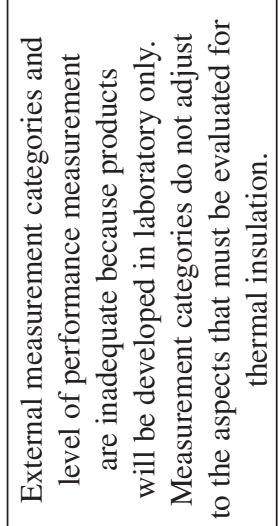 \\
\hline 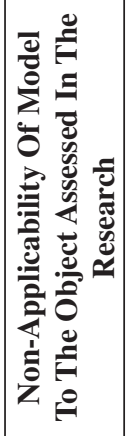 & 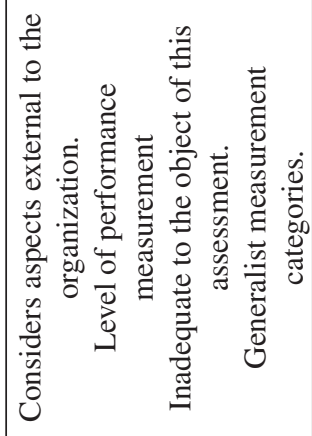 & \multicolumn{3}{|c|}{ 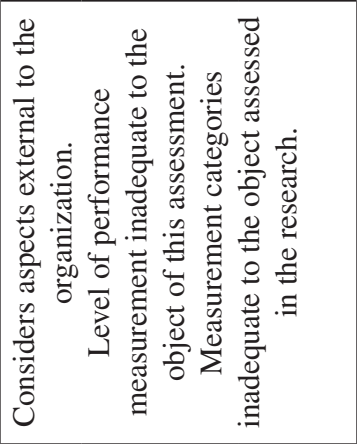 } & 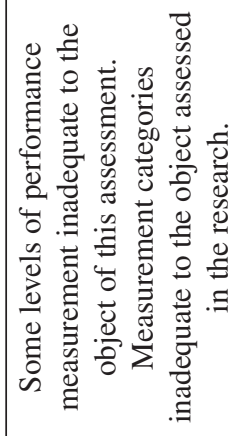 & 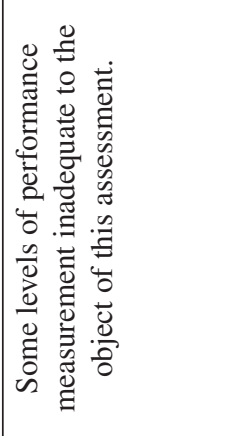 & 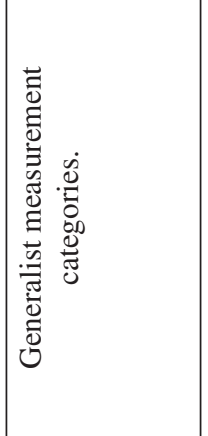 & 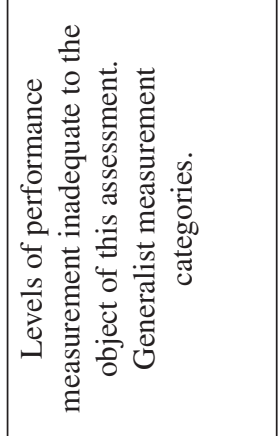 \\
\hline 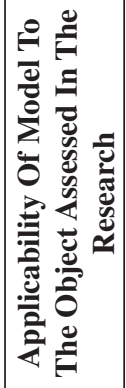 & 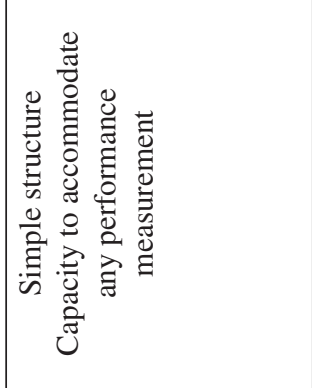 & \multicolumn{3}{|l|}{ 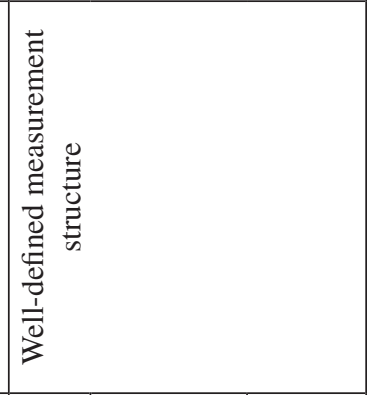 } & 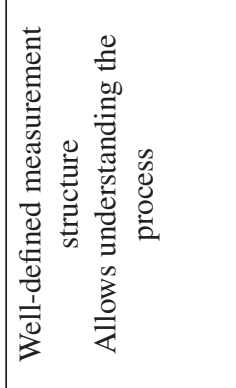 & 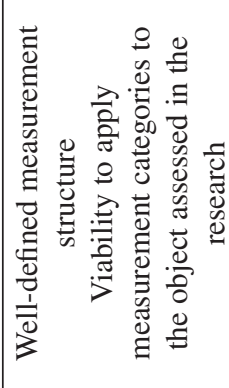 & 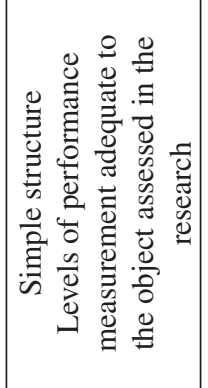 & 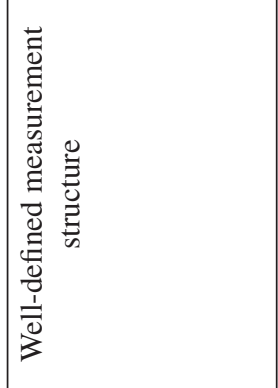 \\
\hline 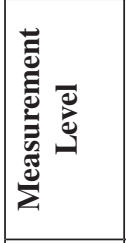 & 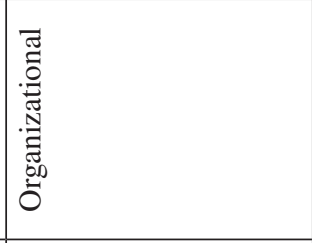 & 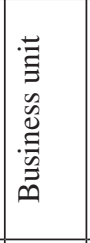 & 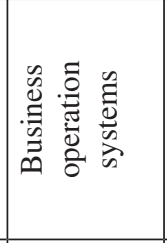 & 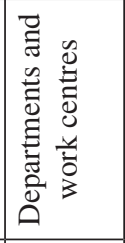 & 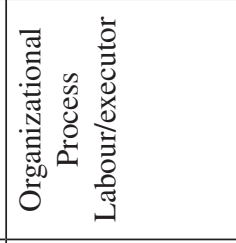 & 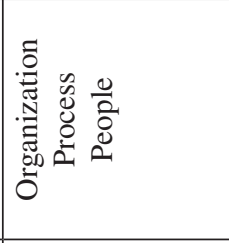 & 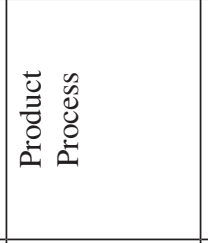 & 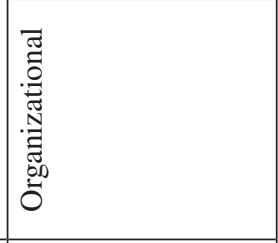 \\
\hline 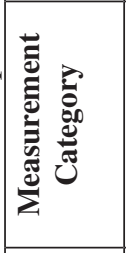 & 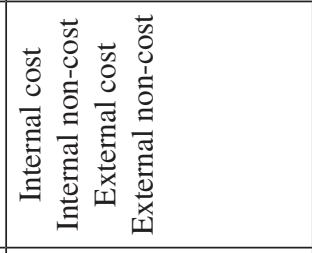 & 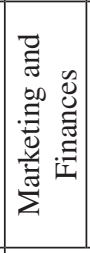 & 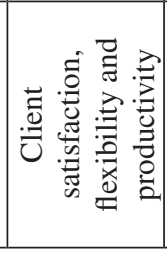 & 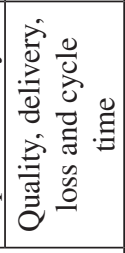 & 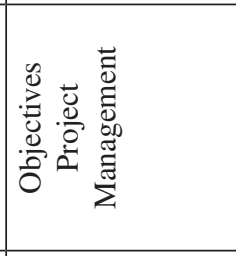 & 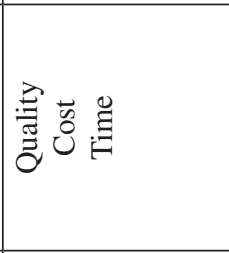 & 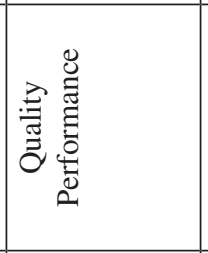 & 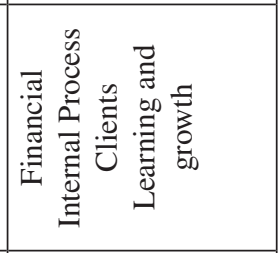 \\
\hline 密 & 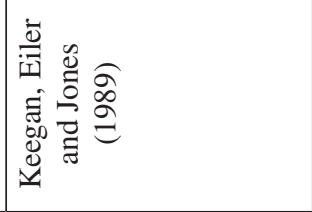 & \multicolumn{3}{|c|}{ 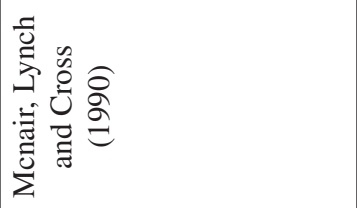 } & 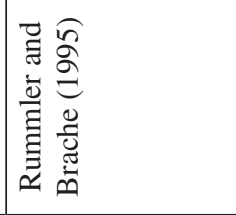 & 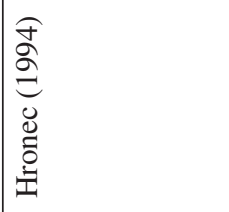 & 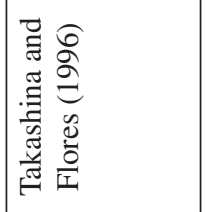 & 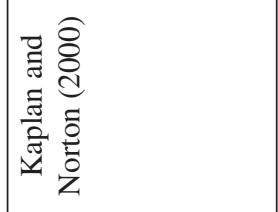 \\
\hline$\frac{\bar{d}}{\mathrm{~d}}$ & 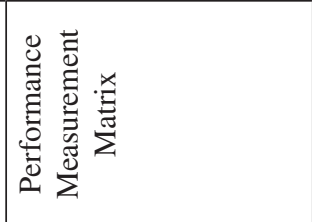 & \multicolumn{3}{|c|}{ 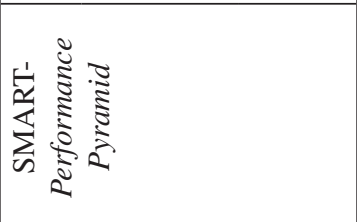 } & 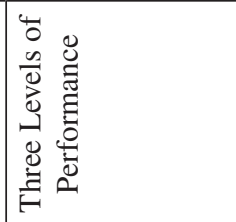 & 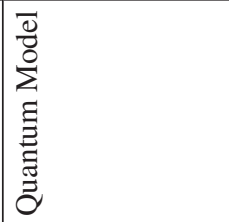 & 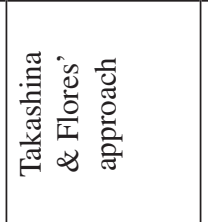 & 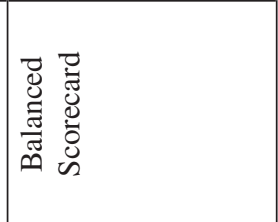 \\
\hline
\end{tabular}


Table 2. Investigation variables.

\begin{tabular}{|c|c|c|c|c|}
\hline Macro-Variable & Definition & Sub-Variable & $\begin{array}{l}\text { Example Of } \\
\text { Indicators }\end{array}$ & $\begin{array}{c}\text { Measurement } \\
\text { Categories }\end{array}$ \\
\hline \multirow[b]{2}{*}{ Economy } & \multirow{2}{*}{$\begin{array}{l}\text { Refers to all costs and/ } \\
\text { or financial aspects } \\
\text { concerning the product. }\end{array}$} & Production costs & $\begin{array}{l}\text { Material costs } \\
\text { Production cost per unit }\end{array}$ & \multirow[b]{2}{*}{ COST } \\
\hline & & Financial Indicators & $\begin{array}{c}\text { Internal Rate or Return } \\
\text { (IRR) } \\
\text { NPV } \\
\end{array}$ & \\
\hline \multirow{3}{*}{ Functionality } & \multirow{3}{*}{$\begin{array}{l}\text { Refers to capabilities and } \\
\text { functions the product } \\
\text { must have. }\end{array}$} & Mechanical properties & $\begin{array}{c}\text { Resistance to compression } \\
\text { Resistance to traction }\end{array}$ & \multirow{3}{*}{$\begin{array}{l}\text { Quality } \\
\text { Time }\end{array}$} \\
\hline & & Thermal properties & $\begin{array}{c}\text { Thermal conductivity } \\
\text { Diffusivity }\end{array}$ & \\
\hline & & Application of insulation & $\begin{array}{l}\text { Time for application of } \\
\text { insulation }\end{array}$ & \\
\hline Security & $\begin{array}{l}\text { Refers to security } \\
\text { requirements that thermal } \\
\text { insulators must comply } \\
\text { with. }\end{array}$ & Fire propagation & Non-combustible material & Qualiity \\
\hline
\end{tabular}

sheet as follows: title, abbreviation, unit, categories of performance measurement, types of indicators, definition, measurement methodology, and analysis methodology. Later, the indicator will be measured for each one of the assessed products, according to the planned methodology.

The analysis of the performance evaluations will be carried out in function of the characteristics and importance of the indicators. It will consider possible elimination criteria, such as any product that may be discarded for not meeting the initial demands. After the analysis is ready, a more adequate thermal insulation classification is created for the application in the substations.

\subsection{Adapting the performance evaluation model}

Ensslin et al. (2007) consider that the use of performance evaluation models boost the capacity of communication in a company, transparency, action alignment, but mainly the ability to understand the assessed products. For these authors the possible success in decision making is directly proportional to the knowledge available to the decision maker.

The decision-making process for selecting thermal insulation must consider aspects concerning economy, functionality and security. The primary function of insulators is to reduce heat transfer between two neighbouring environments, preserving the energy used in maintaining the temperature in one of them (NEIRA, 2005). This way, a model of performance indicators capable of measuring such aspects was defined, thus backing up this evaluation system.

The Quantum Model was used as a basis to describe one performance evaluation model capable of quantifying product performance. In addition, some aspects of the remaining evaluation models studied were considered, which will be described as follows.
The quantum model was chosen over the others because its measurement categories adequately reflect the aspects that must be considered in the evaluation of thermal insulators; levels of performance measurement were adapted considering the remaining models studied and the characteristics of the assessed products.

The levels of performance measurement of the quantum model were considered inadequate for the objective of this evaluation since it will not be necessary to evaluate the level of organization or that of people, for the products will be developed in laboratory only.

The levels of performance measurement were substituted by indicator types, adapted from the Takashina and Flores (1996) approach, that is, quality indicators (product) and performance indicators (process). A performance measurement that considers the process and the product is also recommended by Durán (2001). The adapted performance evaluation matrix is presented in Table 3 .

The three performance measurement categories, set in the quantum matrix, were maintained, for they are able to reflect the three main aspects that must be considered for the selection of thermal insulation.

The remaining performance evaluation models studied present measurements with objectives similar to Hronec's model (HRONEC, 1994); these models also bear some aspects that will not be considered in this research, since they do not conform to the analysis of the assessed product.

The organizational levels were substituted by the indicator levels; however, the product data-sheet was made to promote a joint presentation of measurements of the same type of indicator and thus to make trade-off analysis and identification easier, similar to what is suggested by the SMART model. 
The relations between the measurement categories go on according to the model proposed by (HRONEC, 1994); that is, the relation between them occurs under two perspectives, value (involving cost and quality) and service (involving quality and time).

\subsection{Selecting indicators for application in the model}

Table 4 shows performance indicators selected to evaluate all the aspects of the matrix. It must be said that in this study the indicator value is compromised in this evaluation because it does not rely on an actual factory production to estimate and project the indices that reflect the quality in the production process of the thermal insulation.
For this reason some indicators set beforehand were not selected, such as lead time.

\section{Results and discussion}

Considering the laboratory procedures adopted for the development of the thermal insulation, an industrial production process required for obtaining the respective thermal insulating plaques was determined, according to Figure 4.

\subsection{Measuring indicators for application in the model}

Results from each indicator proposed to evaluate the several types of materials in the composition of vermiculite and EVA thermal insulating plaques.

Table 3. Performance evaluation matrix adapted.

\begin{tabular}{|c|c|c|c|c|}
\hline & \multicolumn{3}{|c|}{ PERFORMANCE EVALUATION MATRIX } & \\
\hline & \multicolumn{2}{|c|}{ - } & \multirow{2}{*}{\begin{tabular}{|c|} 
Service \\
Time
\end{tabular}} & \\
\hline & Cost & Quality & & \\
\hline Product & - Direct Material costs & $\begin{array}{l}\text { - Resistance to traction and } \\
\text { bending } \\
\text { - Resistance to axial } \\
\text { compression } \\
\text { - Thermal Conductivity } \\
\text { - Thermal ... } \\
\text { - Non-combustible material }\end{array}$ & - Setting time & \multirow{2}{*}{$\begin{array}{l}\text { Information on each } \\
\text { indicator } \\
\text { - Title } \\
\text { - Abbreviation } \\
\text { - Unit } \\
\text { - Measurement Category } \\
\text { - Type of Indicator } \\
\text { - Definition } \\
\text { - Measurement } \\
\text { methodology } \\
\text { - Analysis methodology }\end{array}$} \\
\hline Process & $\begin{array}{l}\text { - Production cost } \\
\text { - Internal rate of return } \\
\text { (IRR) } \\
\text { - Net present value (NPV) }\end{array}$ & $\begin{array}{l}\text { - Heat flow } \\
\text { - Cushioning } \\
\text { - Displacement }\end{array}$ & $\begin{array}{l}\text { - Time for insulation } \\
\text { application }\end{array}$ & \\
\hline
\end{tabular}

Source: Adapted from Hronec (1994) and Takashina and Flores (1996).

Table 4. Evaluation matrix with selected indicators.

\begin{tabular}{|c|c|c|c|}
\hline & \multicolumn{3}{|c|}{ PERFORMANCE EVALUATION MATRIX } \\
\hline & Value & \multicolumn{2}{|c|}{\begin{tabular}{|r|r} 
& Service \\
\end{tabular}} \\
\hline & Cost & Quality & Time \\
\hline Product & $\begin{array}{l}\text { Selecting and specifying performance } \\
\text { indicators that translates the cost and/ } \\
\text { or financial aspects of the product, } \\
\text { such as: material cost, direct labour } \\
\text { cost. }\end{array}$ & $\begin{array}{l}\text { Selecting and specifying performance } \\
\text { indicators that quantify the product's } \\
\text { thermal, mechanical and security related } \\
\text { performance, such as: resistance to traction, } \\
\text { resistance to traction, compression, } \\
\text { thermal conductivity and diffusivity, non- } \\
\text { combustible material, resistivity }\end{array}$ & $\begin{array}{l}\text { Selecting and specifying performance } \\
\text { indicators that the translate the product 's } \\
\text { speed or efficiency, such as: } \\
\text { setting time, process lead time. }\end{array}$ \\
\hline Process & $\begin{array}{l}\text { Selecting and specifying performance } \\
\text { indicators that translate the costs and/ } \\
\text { or financial aspects of the product's } \\
\text { production or application such as: } \\
\text { production cost per unit, IRR, NPV, } \\
\text { Pay Back }\end{array}$ & $\begin{array}{l}\text { Selecting and specifying performance } \\
\text { indicators that quantifies the applied } \\
\text { product's thermal and security-related } \\
\text { performance, such as: heat flow, cushioning, } \\
\text { displacement. }\end{array}$ & $\begin{array}{l}\text { Selecting and specifying performance } \\
\text { indicators that quantifies the speed or } \\
\text { efficiency of the product's application } \\
\text { process, such as: time of application of } \\
\text { insulation. }\end{array}$ \\
\hline & $\begin{array}{l}\text { Responsible for the product's } \\
\text { economic analysis, considering the } \\
\text { aspects of production costs (product } \\
\text { and process) and financial indicators } \\
\text { (process) }\end{array}$ & \multicolumn{2}{|c|}{$\begin{array}{l}\text { Responsible for analysing funcionality: thermal properties (product and process quality), } \\
\text { mechanical properties (product quality) and performance os application (process tiem); } \\
\text { and security properties for the application of product (product quality). }\end{array}$} \\
\hline
\end{tabular}

Source: Own elaboration. 


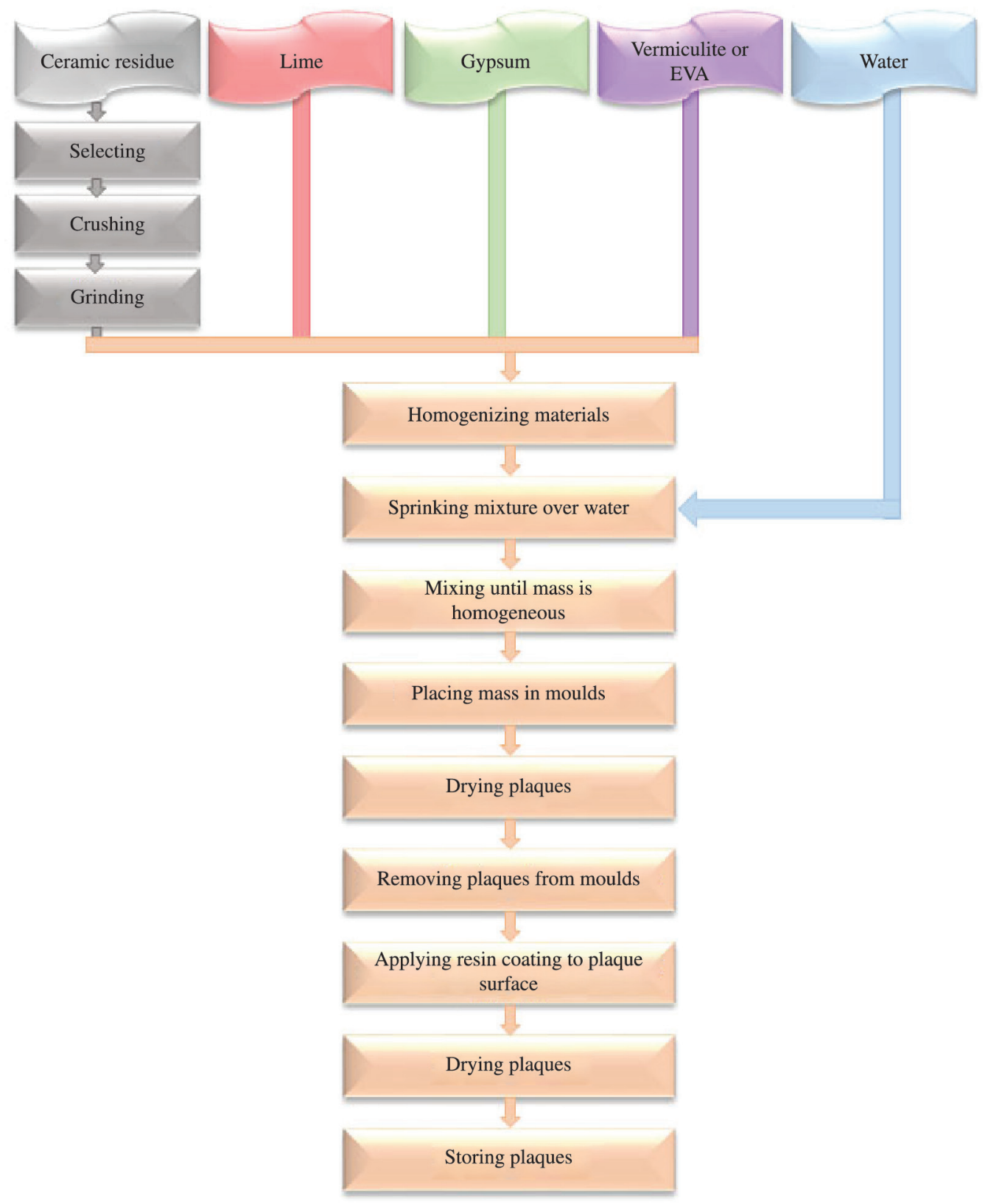

Figure 4. Production Flow chart. Source: own elaboration.

\section{- Material cost}

Table 5 presents the several costs obtained in function of the quantity of items that compose the respective products.

\section{- Production cost}

The indicator production cost was calculated through the estimate of direct and indirect cost, such as: labour, equipment, infra-structure and energy costs (RESENDE, 2011).

Production costs per unit of thermal insulation were: (RESENDE, 2011): US\$1.52 for EVA; US\$2.21 for vermiculite and US\$2.00 for gypsum.

\section{- IRR and PV}

When preparing the cash flows, the following was taken in consideration: initial investment for purchasing the facilities and industrial equipment; yearly growth of sales goals, linear equipment wear along the years, production cost per unit previously calculated, attractiveness rate of 7.5\%; mark-up-based price estimate. It was concluded that all projects are viable; however, gypsum would be the most profitable according to IRR and Present Value (PV). Table 6 presents results for EVA, vermiculite and gypsum thermal insulation (RESENDE, 2011). 


\section{- Non-combustible materials}

The materials that compose thermal insulation were classified for combustion in their own security data-sheets. The results are presented in Table 7.

Heat flow was obtained through the following equation: $Q=\frac{t_{e}-t_{i}}{R_{\text {total }}}$, considering the outside temperature equal to $34^{\circ} \mathrm{C}$ and the inside temperature equal to $25^{\circ} \mathrm{C}$. Total resistance was calculated by adding up the thermal resistance values of each element constituting the wall. Figure 5 illustrates the wall flat plate with composite coating of the layers.

Coated plates measuring $0.4 \mathrm{~m}$ on each side were installed on a wall measuring $1.0 \mathrm{~m}$ in length, as illustrated in Figure 6.

Values calculated for heat flow were (RESENDE, 2011):
EVA: $\dot{Q}=2.571 \mathrm{~W} / \mathrm{m}^{2}$.

Vermiculite: $\dot{Q}=2.601 \mathrm{~W} / \mathrm{m}^{2}$.

Gypsum, $\dot{Q}=2.686 \mathrm{~W} / \mathrm{m}^{2}$.

\section{- Cushioning and displacement}

Values calculated for cushioning and displacement of the thermal insulation were (RESENDE, 2011):

Vermiculite: $m=0,26, \varphi=5.2 h$

EVA: $m=0,25, \varphi=5.3 h$

Gypsum: $m=0,25, \varphi=5.3 \mathrm{~h}$

\section{- Time for the application of insulation}

It was calculated that 11.34 minutes would be necessary to cover an area of $11.20 \mathrm{~m}^{2}$ with the thermal insulation plaque developed with EVA, vermiculite or gypsum, that is, $1.01 \mathrm{~min} / \mathrm{m}^{2}$.

Table 5. Calculating material cost for a thermal insulating plaque.

\begin{tabular}{|c|c|c|c|c|c|}
\hline Thermal Insulation & Material & $\mathbf{C}_{\text {Unit }}$ & Qty & $\mathbf{C}_{\text {Partial }}=\mathbf{C}_{\text {Unit }} \mathbf{x}$ Qty & $\begin{array}{c}\text { CM } \\
\text { (US\$) }\end{array}$ \\
\hline \multirow{4}{*}{ EVA } & Gypsum & $0.156 / \mathrm{kg}$ & 1.1067 & 0.173 \\
\cline { 2 - 5 } & Water & $0.915 / 1$ & 0.8860 & 0.811 \\
\cline { 2 - 6 } & Lime & $0.188 / \mathrm{kg}$ & 0.2656 & 0.050 \\
\cline { 2 - 6 } & Ceramic Residue & $0.050 / \mathrm{kg}$ & 0.3984 & 0.020 \\
\cline { 2 - 6 } & EVA & $0.050 / \mathrm{kg}$ & 0.6640 & 0.033 \\
\hline \multirow{5}{*}{ Vermiculite } & Gypsum & $0.156 / \mathrm{kg}$ & 1.1790 & 0.184 \\
\cline { 2 - 6 } & Water & $0.915 / 1$ & 1.0620 & 0.972 \\
\cline { 2 - 6 } & Lime & $0.188 / \mathrm{kg}$ & 0.2656 & 0.050 \\
\cline { 2 - 6 } & Ceramic Residue & $0.050 / \mathrm{kg}$ & 0.3984 & 0.020 \\
\hline \multirow{3}{*}{ Gypsum } & Vermiculite & $1.310 / \mathrm{kg}$ & 0.4150 & 0.544 \\
\cline { 2 - 6 } & Gypsum & $0.156 / \mathrm{kg}$ & 1.8444 & 0.288 \\
\hline
\end{tabular}

Table 6. Thermal insulation's IRR and NPV.

\begin{tabular}{|c|c|c|c|}
\hline CASH FLOW & $\begin{array}{c}\text { EVA } \\
\text { INSULATION }\end{array}$ & $\begin{array}{c}\text { Vermiculite } \\
\text { INSULATION }\end{array}$ & $\begin{array}{c}\text { Gypsum } \\
\text { INSULATION }\end{array}$ \\
\hline PV(US\$) & $262,569.62$ & $237,575.93$ & $267,924.89$ \\
\hline IRR & $17.6254 \%$ & $11.2134 \%$ & $19.4687 \%$ \\
\hline
\end{tabular}

Source: Own elaboration.

Table 7. Classification of materials used.

\begin{tabular}{|c|c|c|c|}
\hline Thermal insulation & |Material & Material & Final Classification \\
\hline \multirow{4}{*}{ EVA } & Gypsum & Non-combustible & \multirow{4}{*}{ Semi-Combustible Material } \\
\hline & Lime & Non-combustible & \\
\hline & Ceramic Residue & Non-combustible & \\
\hline & EVA & Combustible & \\
\hline \multirow{4}{*}{ Vermiculite } & Gypsum & Non-combustible & \multirow{4}{*}{ Non-combustible Material } \\
\hline & Lime & Non-combustible & \\
\hline & Ceramic Residue & Non-combustible & \\
\hline & Vermiculite & Non-combustible & \\
\hline Gypsum & Gypsum & Non-combustible & Non-combustible Material \\
\hline
\end{tabular}

Source: Own elaboration. 


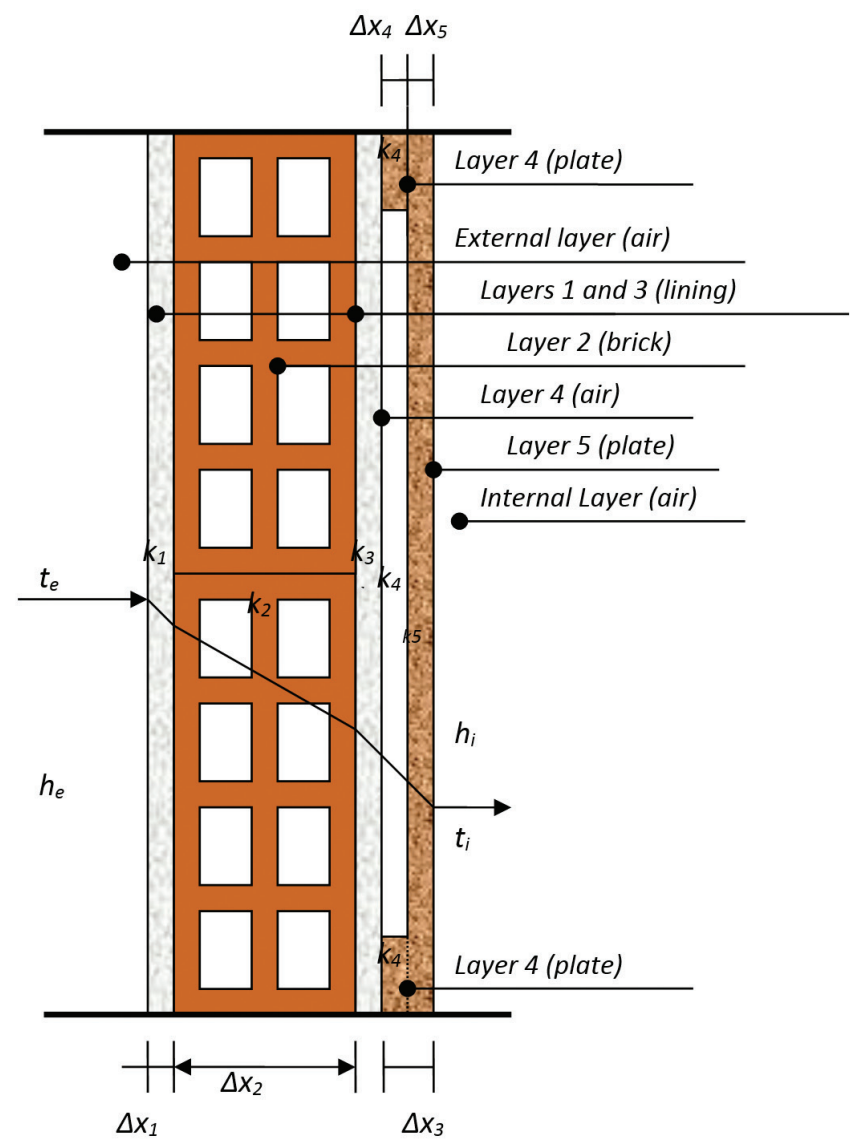

Figure 5. Wall flat plate with composite coating. Source: Oliveira (2009).

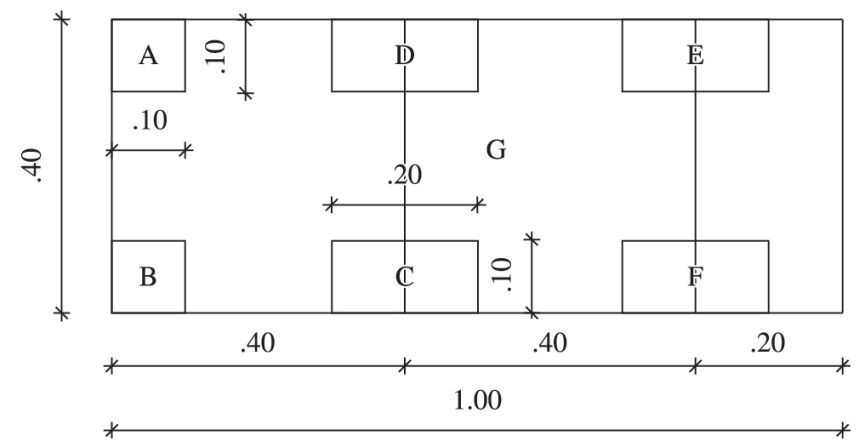

Figure 6. Plate coating area of $0.4 \times 1 \mathrm{~m}^{2}$.

\section{- Resistance to traction at bending, resistance to axial compression. Thermal conductivity, thermal diffusivity and setting time}

Oliveira (2009) obtained these results through laboratory tests done in conformity with pre-established norms. These data were selected and used in the evaluation of the developed products.

\subsection{Analysis of results}

The quantum model was selected and adapted because its measurement categories reflected well the perspectives that should be analysed in the evaluation of thermal insulation; in addition, the levels of performance measurement that did not meet the evaluation demands of a product would be easily adapted by using the perspectives set for the remaining models studied.

By analysing the selection, definition and measurement of the performance indicators - the latter being done through calculations -, specialized laboratory tests and estimates were done based on the technical information of the assessed product. Table 8 summarizes the result of all indicators for each thermal insulator.

By analyzing Table 8, it can be seen that EVA thermal insulation had better thermal performance than the others. However, it was classified as semi-combustible material, which makes it has disadvantaged when compared to the others in the application in electrical substations.

Vermiculite thermal insulation had good mechanical and security performance and its thermal performance is considered to be good. However, it did not do better than the other insulators in any other indicator. The main disadvantage of the vermiculite insulation concerns cost performance.

Gypsum thermal insulation had good thermal performance and reasonable mechanical performance, good security performance and disadvantage as to cost, even if it had better performance concerning IRR and PV, which evaluate the viability of the project of product production.

The measurement category called quality is made of three perspectives. Figure 7 shows the performance of products in this category, considering the aspects of mechanical performance (axis $\mathrm{x}$ ), thermal performance (axis y) and safety (size of markers), which help visualize the product performance in this measuring category.

The chart of quality performance of insulation in the Figure 7 shows that the EVA insulation has better thermal performance, ain nd mechanical performance equivalent to the gypsum insulation. Gypsum insulation has better security marks, together with vermiculite insulation.

\subsection{Classification of developed thermal insulation}

A performance measurement system takes up a hierarchical character as it uses intermediate variables of state to represent the complex reality of one strategy or operation. One hierarchy is set from the knowledge the decision maker has about the situation of interest (SELLITO; BORCHARDT; PEREIRA, 2006).

Figure 8 shows the performance evaluation of the products, considering the following performance measurement categories: cost (axis X), quality (axis Y) and time (size of markers). 
Table 8. Comparison of indicator results.

\begin{tabular}{|c|c|c|c|c|}
\hline Indicator & EVA & Vermiculite & Gypsum & Best \\
\hline Material Cost (US\$) & 1.09 & 1.77 & 1.64 & EVA \\
\hline Production Cost Per Unit (US\$) & 1.52 & 2.21 & 2.00 & EVA \\
\hline IRR & $17.62 \%$ & $11.21 \%$ & $19.47 \%$ & $\begin{array}{l}\text { EVA, gypsum and } \\
\text { vermiculite }\end{array}$ \\
\hline Present Value (US\$) & 262569.62 & 237575.93 & 267924.89 & Gypsum \\
\hline Resistance to traction at compression & $1.5 \mathrm{MPa}$ & $1.6 \mathrm{MPa}$ & $2.0 \mathrm{MPa}$ & Gypsum \\
\hline Resistance to axial compression & 3.0MPa & $2.8 \mathrm{MPa}$ & $2.5 \mathrm{MPa}$ & EVA \\
\hline Thermal conductivity & $0.26 \mathrm{~W} / \mathrm{m}^{\circ} \mathrm{C}$ & $0.27 \mathrm{~W} / \mathrm{m}^{\circ} \mathrm{C}$ & $0.30 \mathrm{~W} / \mathrm{m}^{\circ} \mathrm{C}$ & EVA \\
\hline Thermal diffusivity & $0.21 \times 10^{-6} \mathrm{~m}^{2} / \mathrm{s}$ & $0.23 \times 10^{-6} \mathrm{~m}^{2} / \mathrm{s}$ & $0.25 \times 10^{-6} \mathrm{~m}^{2} / \mathrm{s}$ & EVA \\
\hline Non-combustible material & $\begin{array}{c}\text { semi-combustible } \\
\text { material }\end{array}$ & $\begin{array}{c}\text { Non-combustible } \\
\text { material }\end{array}$ & $\begin{array}{c}\text { Non-combustible } \\
\text { material }\end{array}$ & $\begin{array}{l}\text { Vermiculite and } \\
\text { gypsum }\end{array}$ \\
\hline Heat flow & $2.571 \mathrm{~W} / \mathrm{m}^{2}$ & $2.601 \mathrm{~W} / \mathrm{m}^{2}$ & $2.686 \mathrm{~W} / \mathrm{m}^{2}$ & EVA \\
\hline Cushioning & $0 . .25$ & $0 . .26$ & $0 . .25$ & EVA and gypsum \\
\hline Displacement & $5 . .3 \mathrm{~h}$ & $5 . .2 \mathrm{~h}$ & $5 . .3 \mathrm{~h}$ & EVA and gypsum \\
\hline Setting time & $38 . .37 \mathrm{~min}$ & $26.48 \mathrm{~min}$ & $14.00 \mathrm{~min}$ & Gypsum \\
\hline Time for application of insulation & $1 . .01 \mathrm{~min} / \mathrm{m}^{2}$ & $1.01 \mathrm{~min} / \mathrm{m}^{2}$ & $1.01 \mathrm{~min} / \mathrm{m}^{2}$ & $\begin{array}{c}\text { EVA, vermiculite and } \\
\text { gypsum }\end{array}$ \\
\hline
\end{tabular}

Source: Own elaboration.

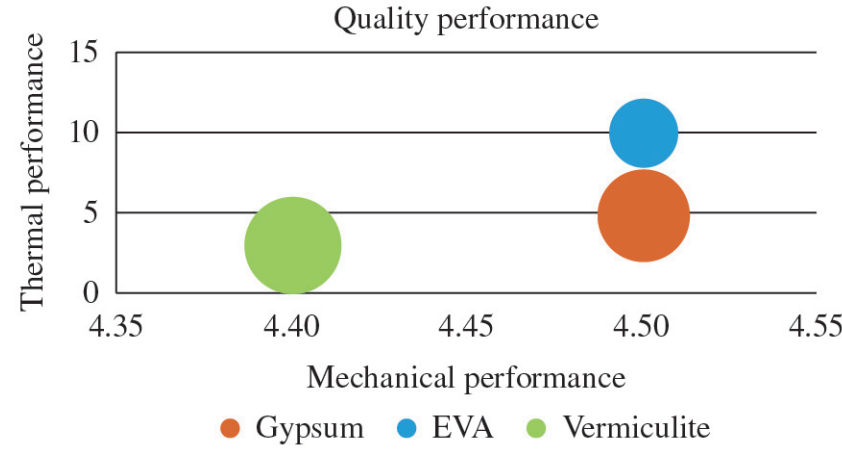

Figure 7. Chart for Quality Performance of Insulation. Source: own elaboration.

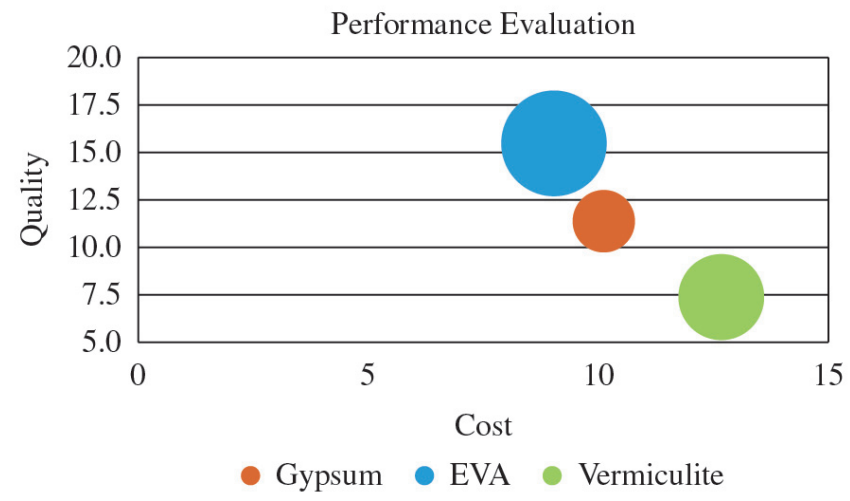

Figure 8. Performance evaluation for thermal insulation. Source: own elaboration.

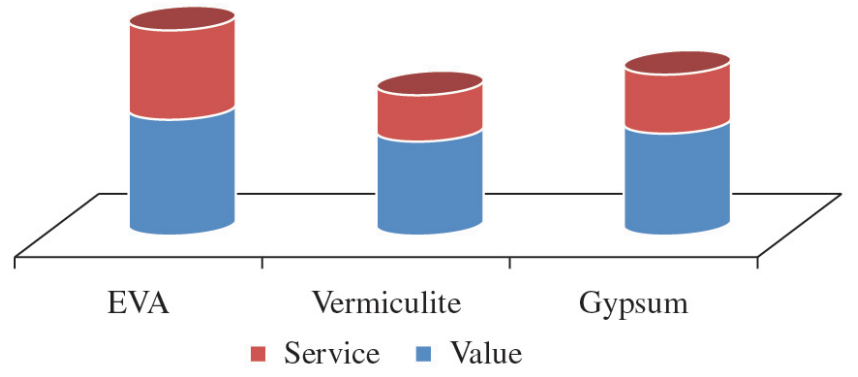

Figure 9. Relations between measurement categories. Source: own elaboration.

The performance evaluation chart in the Figure 8 shows that EVA insulation has the best performance for the cost and quality measurement categories. Gypsum insulation has the best performance concerning the time category.

Next, the insulation performance will be analysed based on the relations of the measuring categories in Hronec's model (HRONEC, 1994). The adapted model maintained the relations between measurement categories according to the original model, which can be described as: value generation, through the relation of cost and quality categories; and service excellence, through the relation between quality and time categories.

By taking the three dimensions of the matrix into consideration, analysed through Figures 7 and 8, it can be concluded that the most adequate product for the application in electrical substations is EVA thermal insulation, followed by gypsum and finally, vermiculite as shown Figure 9 . 


\section{Conclusions}

- EVA thermal insulation had better thermal performance than the others. However, it was classified as semi-combustible material, which makes it has disadvantaged when compared to the others in the application in electrical substations;

- Vermiculite thermal insulation had good mechanical and security performance and its thermal performance is considered to be good. However, it did not do better than the other insulators in any other indicator. The main disadvantage of the vermiculite insulation concerns cost performance;

- Gypsum thermal insulation had good thermal performance and reasonable mechanical performance, good security performance and disadvantage as to cost, even if it had better performance concerning Present Value Cost (PV), which evaluate the viability of the project of product production;

- The quality performance of insulation the EVA insulation has better thermal performance, and mechanical performance equivalent to the gypsum insulation. Gypsum insulation has better security marks, together with vermiculite insulation;

- The performance evaluation chart the EVA insulation has the best performance for the cost and quality measurement categories. Gypsum insulation has the best performance concerning the time category;

- By taking the three dimensions of the matrix into consideration analysed, it can be concluded that the most adequate product for the application in electrical substations is EVA thermal insulation, followed by gypsum and vermiculite.

\section{Acknowledgements}

This paper was developed in the scope of a Research Project financed by Brazilian Agency CNPq (Conselho Nacional de Desenvolvimento Científico Tecnológico).

\section{References}

BEZERRA, A. J. V. Utilização do resíduo da indústria de calçados (EVA) como agregado leve na produção de blocos vazados de concreto para alvenaria sem função estrutural. UFPB/CCT, 2002. 100 f. Dissertação (Mestrado em Engenharia)-Universidade Federal da Paraíba, João Pessoa, 2002.

BITITCI, U. S. et al. Dynamics of performance measurement and organisational culture. International Journal of Operations \& Production Management, v. 26, n. 12, p. 1325-1350, 2006. http://dx.doi.org/10.1108/01443570610710579

BOURNE, M. et al. Designing, implementing and updating performance measurements systems. International Journal of Operations and Production
Management, v. 20, n. 7, p. 754-771, 2000. http://dx.doi. org/10.1108/01443570010330739

CHUNG, S. H.; PEARN, W. L. P.; LEE, A. Measuring production performance of different product mixes in semiconductor fabrication. International Journal of Industrial Engineering: Theory, Applications and Practice, v. 13, n. 1, p. 5-17, 2006.

DÍAZ, M. S.; GIL, M. J. Á.; MACHUCA, J. A. D. Performance measurement systems, competitive priorities, and advanced manufacturing technology. International Journal of Operations \& Production Management, v. 25, n. 8, p. 781799, 2005 http://dx.doi.org/10.1108/01443570510608600

DIGALWAR, A. K.; SANGWAN, K. S. An overview of existing performance measurement frameworks in the context of world class manufacturing performance measurement. International Journal of Services and Operations Management, v. 9, n. 1, p. 60-82, 2011. http:// dx.doi.org/10.1504/IJSOM.2011.040322

DURÁN, A. O. Sistemática para medição de desempenho em áreas de desempenho de produtos. In: CONGRESSO BRASILEIRODEGESTÃODEDESENVOLVIMENTODE PRODUTO, 3., 2001, Florianópolis. Anais... Florianópolis: Universidade Federal de Santa Catarina, 2001.

DUTRA, A. Metodologia para avaliar e aperfeiçoar o desempenho organizacional: incorporando a dimensão integrativa à MCDA construtivista-sistêmico-sinergética. 2003. 320 f. Tese (Doutorado em Engenharia de Produção)Universidade Federal de Santa Catarina, Florianópolis, 2003.

ENSSLIN, L. et al. Avaliação de Desempenho: objetivos e dimensões. In: SEMINÁRIO DE AVALIAÇÃO DE DESEMPENHO DO SETOR PÚBLICO, 1., 2007, Florianópolis. Anais... Available from: <http://www.spg. sc.gov.br>. Access in: 4 Mar. 2009.

FRANCESCHINI, F.; GALETTO, M.; MAISANO, D. Classification of performance and quality indicators in manufacturing. International Journal of Services and Operations Management, v. 2, n. 3, p. 294-311, 2006. http://dx.doi.org/10.1504/IJSOM.2006.009862

GODINI, M. Q. Os princípios do balanced scorecard: uma contribuição para a avaliação do desempenho da gestão ambiental empresarial. 2007. 187 f. Dissertação (Mestrado em Gestão Integrada em Saúde do Trabalho e Meio Ambiente)-Serviço Nacional de Aprendizagem Comercial - SENAC, São Paulo, 2007.

HANSON, J. D.; MELNYK, S. A.; CALANTONE, R. A. Defining and measuring alignment in performance management. International Journal of Operations \& Production Management, v. 31, n. 10, p. 1089-1114, 2011. http://dx.doi.org/10.1108/01443571111172444 
HRONEC, S. M. Sinais vitais: usando medidas do desempenho da qualidade, tempo e custo para traçar a rota para o futuro de sua empresa. São Paulo: Makron Books, 1994.

KAPLAN, R. S.; NORTON, D. P. Organização orientada para a estratégia: como as empresas que adotam o balanced scorecard prosperam no novo ambiente de negócios. Rio de Janeiro: Campus, 2000.

KEEGAN, D. P.; EILER, R. G.; JONES, C. R. Are your performance measures obsolete? Management Accounting, v. 70, n. 12, p. 45-50, 1989.

MACAMBIRA, P. M. O concreto em Belém do Pará: uma visão analítica de seus components, mão-de-obra e patologias. 2001. Monografia (Trabalho de Conclusão de Curso)-Universidade da Amazônia, Belém, 2001.

MARELli, A. G. Avaliação de requisitos para o desenvolvimento de sistemas de indicadores de desempenho em obras de construção civil sob o recorte analítico de redes de empresas. 2005. 115 f. Dissertação (Mestrado em Engenharia de Produção)-Universidade de São Paulo, São Carlos, 2005.

MCNAIR, C. J.; LYNCH, R.; CROSS, K. Do financial and non-financial measures have to agree? Management Accounting, v. 72, n. 5, p. 28-36, 1990.

MELO, M. O. B. C. et al. Energy efficiency in building installations using thermal insulating materials in Brazil Northeast. Energy and Buildings, v. 47, p. 35-43, 2012. http://dx.doi.org/10.1016/j.enbuild.2011.11.021

MELO, M.; SILVA, L. B.; CAMPELO, S. Industries energy efficiency analyses in Northeast Brazil: proposal of methodology and case studies. International Journal of Industrial Engineering: Theory, Applications and Practice, v. 19, n. 11, 2012.

NEIRA, D. S. M. (2005). Fibras de sisal (Agave sisalana) como isolante térmico de tubulações. 2005. $79 \mathrm{f}$. Dissertação (Mestrado em Engenharia Mecânica)Universidade Federal do Rio Grande do Norte, Natal, 2005.

NUINTIN, A. A. O desenvolvimento de indicadores do desempenho e da qualidade para o processo de produção: estudo de casos do processo de produção do café. 2007. 143 f. Dissertação (Mestrado em Controladoria e Contabilidade)-Universidade de São Paulo, Ribeirão Preto, 2007.

OLIVEIRA, M. P. Materiais compósitos à base de gesso contendo EVA (Etileno Acetato de Vinila) e vermiculita: otimização de misturas e propriedades termomecânicas. 2009. 186 f. Tese (Doutorado em Engenharia Mecânica)Universidade Federal da Paraíba, João Pessoa, 2009.
O'MARA, C. E.; HYLAND, P. W.; CHAPMAN, R. L. Performance measurement and strategic change. Managing Service Quality, v. 8, n. 3, p. 179-182, 1998.

RAY, A.; SARKAR, B.; SANYAL, S. An exploratory analysis of optimizing product mix through heuristic: an eclectic decision. International Journal of Industrial Engineering: Theory, Applications and Practice, v. 18, n. 9 , p. 462, 2011.

RESENDE, S. R. Adaptação de um modelo de avaliação de desempenho para produtos: o caso de isolantes térmicos desenvolvidos para aplicação nas subestações elétricas do nordeste brasileiro. 2011. 132 f. Dissertação (Mestrado em Engenharia de Produção)-Universidade Federal da Paraiba, João Pessoa, 2011.

RUMMLER, G.; BRACHE, A. Improving performance, how to manage the white space onthe organization chart. San Francisco: Jossey-Bass. 1995.

SELLITO, M.; BORCHARDT, M.; PEREIRA, G. Avaliação multicriterial de desempenho: um estudo de caso na indústria de transporte coletivo de passageiros. Gestão \& Produção, v. 13, n. 2, p. 339-352, 2006. http://dx.doi. org/10.1590/S0104-530X2006000200014

SILVA, E. R. S. Sistemática para estruturação de um sistema de medição do desempenho hierarquizado em empresas com parceria entre cliente e fornecedor. 2006. $201 \mathrm{f}$. Tese (Doutorado em Engenharia de Produção)-Universidade Federal de Santa Catarina, Florianópolis, 2006.

SINGH, P. J.; MITTAL, V. K.; SANGWAN, K. S. Development and validation of performance measures for environmentally conscious manufacturing. International Journal of Services and Operations Management, v. 14, n. 2, p. 197 220, 2013. http://dx.doi.org/10.1504/IJSOM.2013.051829

TAO, C. J.; CHEN, S. C.; HSIEH, C. T. Assessing product satisfaction performance using 6-sigma methodology and $\mathrm{S} / \mathrm{N}$ ratio approach: the case of PDA. International Journal of Industrial Engineering: Theory, Applications and Practice, v. 16, n. 9, p. 51-60, 2009.

TAKASHINA, N. T.; FLORES, M. C. X. Indicadores de qualidade e do alto desempenho: como estabelecer e medir resultados. Rio de Janeiro: Qualitymard, 1996.

WU, F. C.; WANG, H. M.; FAN, T. Y. Quality design of taguchi's digital dynamic systems. International Journal of Industrial Engineering: Theory, Applications and Practice, v. 17, n. 1, p. 36-47, 2010. 